\title{
Structure-Based in Silico Study of 6-Gingerol, 6-Ghogaol, and 6-Paradol, Active Compounds of Ginger (Zingiber officinale) as COX-2 Inhibitors
}

\author{
Nyi Mekar Saptarini ${ }^{1}$, Evi Yanti Sitorus ${ }^{1} \&$ Jutti Levita $^{1}$ \\ ${ }^{1}$ Faculty of Pharmacy, Padjadjaran University, West Java, Indonesia \\ Correspondence: Nyi Mekar Saptarini, Faculty of Pharmacy, Padjadjaran University, West Java 43565, Indonesia. \\ Tel: 62-815-607-8248. E-mail: n_mekars@yahoo.com
}

Received: February 16, 2013 Accepted: April 15, 2013 Online Published: June 6, 2013

doi:10.5539/ijc.v5n3p12

URL: http://dx.doi.org/10.5539/ijc.v5n3p12

\begin{abstract}
Ginger's (Zingiber officinale) phenolic compounds, that are 6-gingerol, 6-shogaol, and 6-paradol, have been proven to show anti-inflammatory activity. The purpose of this paper was to discover whether these compounds are potential to be used as COX-2 inhibitors through structure-based in silico study, which is based on the character of the receptor. Docking was performed to the binding pockets of both COX-1 and COX-2 enzymes, to examine their selective character on COX-2. The binding pockets used in this project were the sites where flurbiprofen and SC-58, crystallized in the enzymes. The scoring value of the interaction of 6-gingerol, 6-shogaol, and 6-paradol with COX-1 were $-7.40,-7.27$, and $-7.20 \mathrm{kcal} / \mathrm{mol}$, while with COX-2 were -7.97, -8.10 , and $-7.80 \mathrm{kcal} / \mathrm{mol}$, respectively. $\mathrm{K}_{\mathrm{i}}$ value to $\mathrm{COX}-1$ were $3.78,4.66$, and $5.30 \mu \mathrm{M}$, while to COX-2 were $1.46,1.16$, and $1.93 \mu \mathrm{M}$, respectively. We also calculated the selectivity index value of these compounds to COX-2 and resulted an interval of 0.2 to 0.4 , which indicated that all tested compounds could be classified as preferential COX-2 inhibitors. It can be concluded that 6-gingerol, 6-shogaol, and 6-paradol could be developed as COX-2 inhibitors.
\end{abstract}

Keywords: cyclooxygenase, in silico study, 6-gingerol, 6-shogaol, 6-paradol, structure-based drug design

\section{Introduction}

Cyclooxygenase (COX) enzymes play an important role in inflammatory response, i.e catalyzed the prostaglandins biosynthesis. These enzymes are visualized as homodimers that contain 587 amino acid residues in each chain with molecular weight of 67230 Daltons. Two isoforms, knows as COX-1 and COX-2, have similar amino acid residues composition and hydrophobic channel as binding pocket (Fabiola et al., 2001). The COX binding pocket contain Val116, Arg120, Val349, Leu352, Tyr355, Leu359, Tyr385, Trp387, Ile523 (for COX-1 or Val523 for COX-2), Gly526, Ser530, and Leu531 (Picot et al., 1994). The most important amino acid residue is Tyr385 that catalyzed the transformation of arachidonic acid to PGG2. COX-2 had larger binding pocket due to the substitution of valine to isoleucine at position 523. COX-1 and COX-2 differ in their distribution and regulatory functions. COX-1 is expressed in cells and normal tissues physiological functions. COX-2 is induced by mediators of inflammation in pathological conditions. Inhibition of both COX-1 and COX-2 with non-selective inhibitors lead to renal and gastrointestinal side effects due to inhibition of COX-1 (Kurumbail et al., 1996).

Ginger (Zingiber officinale) contains phenolic compounds that had anti-inflammatory activity, i.e gingerol, shogaol, and paradol (Chung et al., 2001; Ippoushi et al., 2003; Levy et al., 2006). Previous studies showed that gingerol $\left(\mathrm{IC}_{50}\right.$ values is $\left.5.5 \mu \mathrm{M}\right)$ inhibited prostaglandins biosynthesis (Kiuchi et al., 1982) and 6-gingerol $(50-100 \mathrm{mg} / \mathrm{kg}$ ) inhibited carrageenan-induced inflammation (Fabiola et al., 2001), 6-shogaol $(6.2 \mathrm{mg} / \mathrm{kg}$ in 0.2 $\mathrm{mL}$ peanut oil) reduced knee inflammation in mice injected by Complete Freund's Adjuvant (Levy et al., 2006). 6-paradol and derivatives inhibited ear edema in mice induced by 12-O-tetradecanoylphorbol-13-acetate (Chung et al., 2001).

In this paper, 6-gingerol, 6-shogaol and 6-paradol were investigated whether these compounds are potential to be used as COX-2 inhibitors through structure-based in silico study. Their binding modes were compared with SC-58, a selective COX-2 inhibitor, to determine their selectivity to COX-2. Structure similarity of tested 
compounds with SC-58 is not considered important due our structure-based method approach which is based on the character of the receptor.

\section{Method}

\subsection{Materials}

A Windows XP Professional (2010) computer with Genuine Intel Core ${ }^{T M} 2$ Duo $2.0 \mathrm{GHz}, 250 \mathrm{~GB}, 800 \mathrm{MHz}$ FSB 2 MB L2 cache and RAM 2.0 GB capacity of memory used in this computational study. The X-ray crystallographic 3D structures of COX-1 (PDB code: 1EQH) and COX-2 (PDB code: 1CX2) were downloaded from online Protein Data Bank (http://www.rcsb.org/pdb).

\subsection{Molecular Modeling}

The 2D and 3D structures of 6-gingerol, 6-shogaol, 6-paradol, and SC-58 were built by using ChemBio 3D 12.0.2 free trial (Serial Number: 186-410320-7811) downloaded from www.cambridgesoft.com. Energy minimization of each molecule and ligands' QSAR properties calculation were carried out by using AM1 method with Polak-Ribiere algorithm from HyperChem v.8.0. Professional Edition (verification code: 0-28331) downloaded from http://www.hyper.com.

\subsection{Macromolecules Preparation}

The X-ray crystallographic 3D structures of COX-1 (PDB code: 1EQH) and COX-2 (PDB code: 1CX2) were downloaded from online Protein Data Bank (http://www.rcsb.org/pdb/). Hydrogens were added to all COX enzymes PDB crystal structures followed by calculating their partial charges. SwissPDBViewer v.4.01 (GlaxoSmithKline R\&D, downloaded from http://www.expasy.org) was used to separate the monomer of the macromolecules.

\subsection{Ligand-Enzyme Docking}

Ligand-enzyme docking was applied to understand the molecular interaction of 6-gingerol, 6-shogaol, and 6-paradol with COX-1 and COX-2. Docking was simulated with AutoDock Vina in MGLTools v1.5.6 (Molecular Graphics Laboratory, The Scripps Research Institute, downloaded from http://mgltools.scripps.edu). The interaction between 6-gingerol, 6-shogaol, and 6-paradol with both of the COX enzymes was analyzed and compared with SC-58, selective COX-2 inhibitor.

\section{Results and Discussion}

\subsection{Molecular Modeling}

All three phenolic compounds of ginger, 6-gingerol, 6-shogaol, and 6-paradol (Figure 1), are hydrophobic (cLog P 3.78 to 4.69), due to their aromatic ring and methoxy group. The similarity of SC-58 and our tested compounds is that they show anti-inflammatory activity as proven by in vitro study. Although, their structures are not similar, they indicate the same hydrophobicity character as shown by their $\log \mathrm{P}$ values (Table 1). This hydrophobicity is important because COX-2 binding pocket is a hydrophobic channel (Fabiola et al., 2001).<smiles>COc1cc(CCC(=O)CC(C)C)ccc1O</smiles>

(a)<smiles>CCC=CC(=O)CCc1ccc(O)c(OC)c1</smiles>

(b)<smiles>CCCCC(=O)CCc1ccc(O)c(OC)c1</smiles>

(c)

Figure 1. 2D Structure of 6-gingerol (a), 6-shogaol (b), and 6-paradol (c) 
Table 1. Analysis of ligands (calculated by using Portable HyperChem Release 8.0.7)

\begin{tabular}{cccc}
\hline Ligand & stable conformational energy $\left(\mathrm{kcal} \mathrm{mol}^{-1}\right)$ & $\operatorname{cLog} \mathrm{P}$ & Volume $\left(\AA^{3}\right)$ \\
\hline 6-gingerol & -4689.76 & 3.78 & 976.83 \\
6-shogaol & -4453.71 & 4.77 & 949.64 \\
6-paradol & -4586.05 & 4.69 & 961.42 \\
SC-58 & -4026.33 & 4.24 & 976.26 \\
\hline
\end{tabular}

Geometry optimization of the ligands was performed by AM1 method because this method is used to predict small molecules with better precision. It is also able to calculate energy generated by hydrogen bonding of the $\mathrm{O}$ and $\mathrm{N}$ atoms (Marcel Dekker Incorporation, 2004).

\subsection{Macromolecules Preparation}

Flurbiprofen and SC-58 which were co-crystallized in the structure of $1 \mathrm{EQH}$ and 1CX2, respectively, were extracted and redocked into their original binding pockets. The RMSD values resulted from these ligands redocking were $1.54 \AA$ and $0.85 \AA$ respectively for flurbiprofen and SC-58, which were less than $2.0 \AA$, a value typically used in evaluating the success of docking algorithms, indicating the docking methods were valid (Figure 2). There was a shift in the position of the ligands which shown through different amino acid residues in the pocket. The redocking results was categorized as close (Jones et al., 1997).

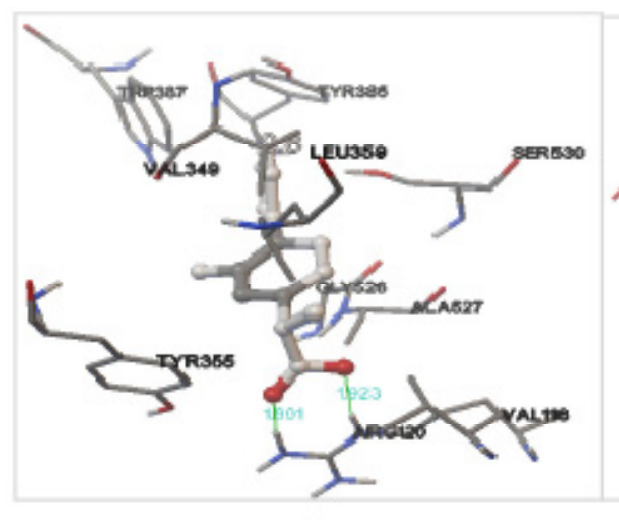

(a)

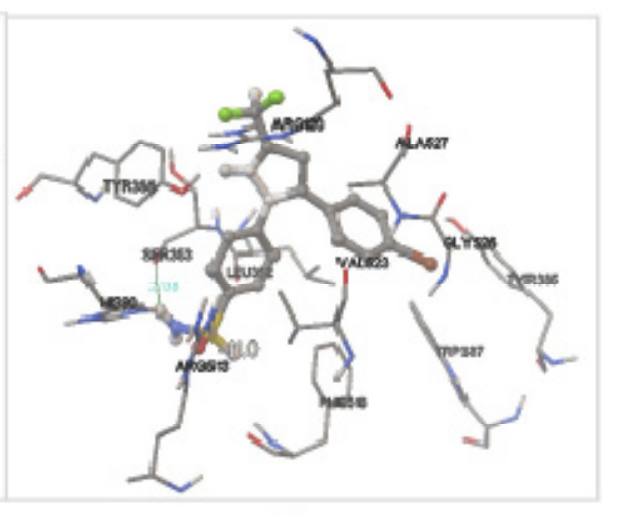

(b)

Figure 2. Redocking of (a) flurbiprofen into the binding pocket of COX-1 and (b) SC-58 into the binding pocket of COX-2. Ligands are visualized by stick and ball model. Green lines indicates hydrogen bonds which are formed between ligand and the amino acid residues in the binding pocket of COX-1 and COX-2 


\subsection{Ligand-Enzyme Docking}

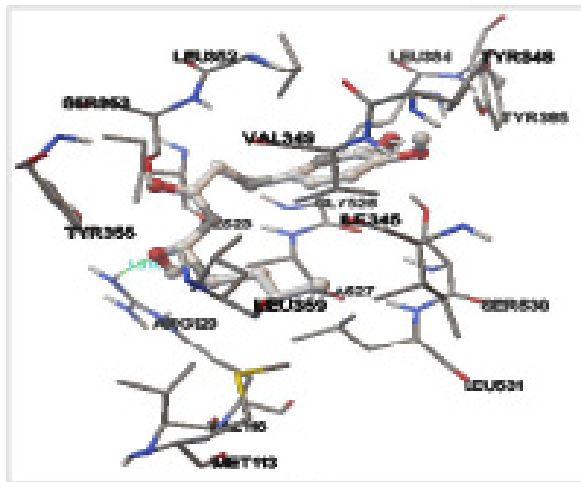

(a)

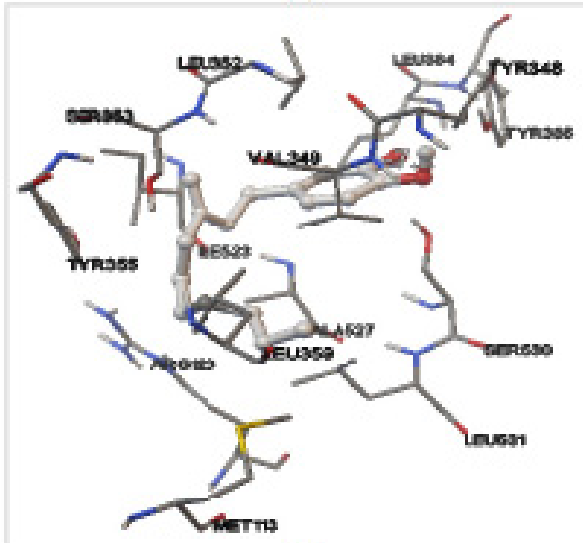

(c)

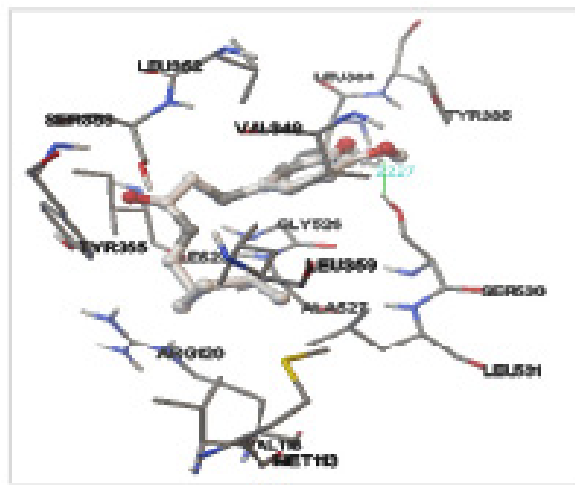

(b)

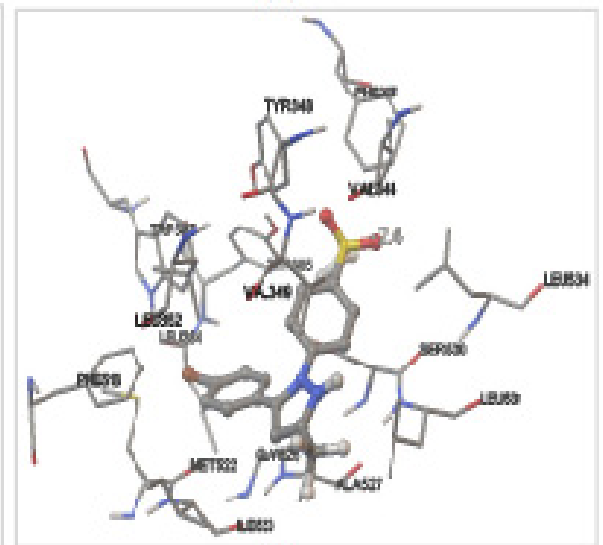

(d)

Figure 3. Docking of 6-gingerol (a), 6-shogaol (b), 6-paradol (c), and SC-58 (d) into the binding site of COX-1. Ligands are visualized by stick and ball model. Green lines indicates hydrogen bonds which are formed between ligand and the amino acid residues in the binding pocket of COX-1 


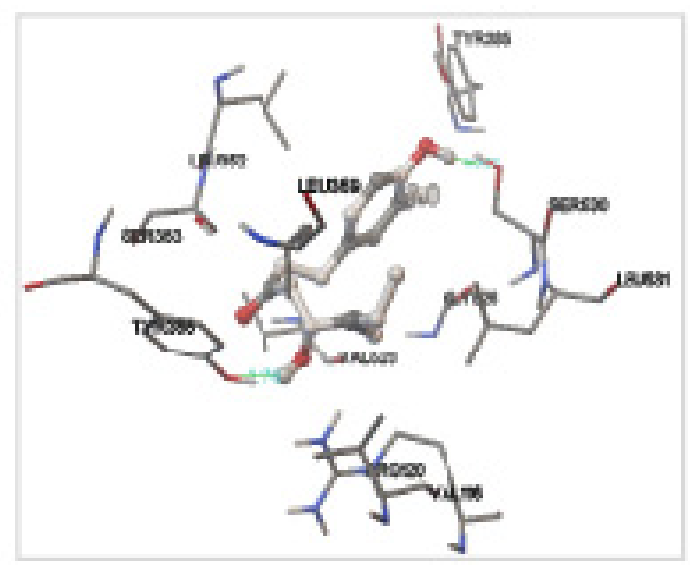

(a)

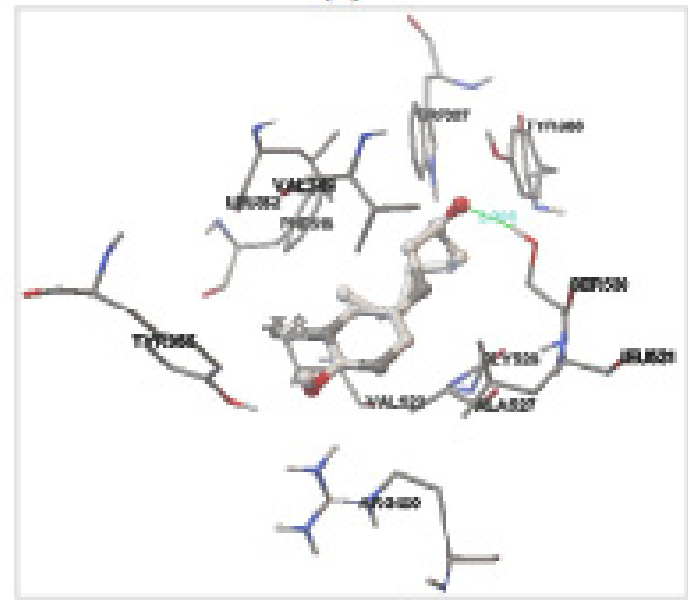

(c)

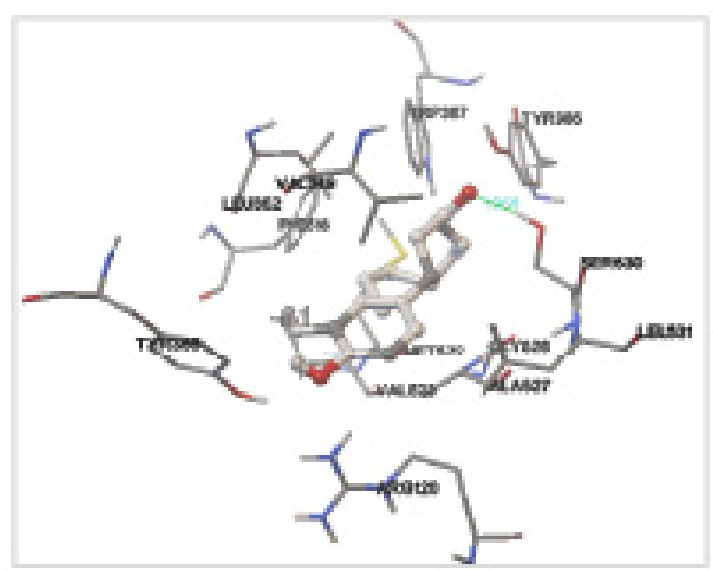

(b)

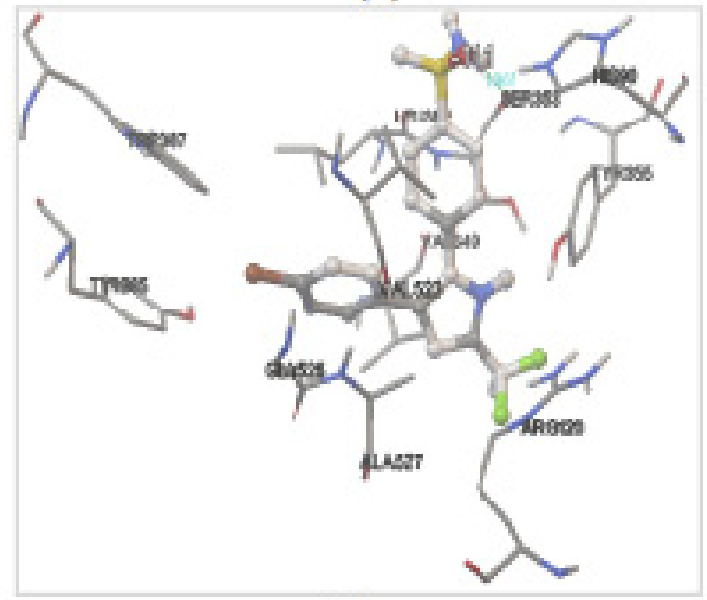

(d)

Figure 4. Docking of 6-gingerol (a), 6-shogaol (b), 6-paradol (c), and SC-58 (d) into the binding site of COX-2. Ligands are visualized by stick and ball model. Green lines indicates hydrogen bonds which are formed between ligand and the amino acid residues in the binding pocket of COX-2

SC-58 was docked on COX-1 and COX-2 and the results were compared to those of the tested compounds. This step was performed to calculate its selectivity index value as a standard comparison for the tested compounds. As we have already recognized that SC-58 is a selective COX-2 inhibitor. 
Table 2. Docking values with COX-1 and COX-2

\begin{tabular}{|c|c|c|c|c|}
\hline \multicolumn{5}{|c|}{ COX-1 } \\
\hline Ligand & $\begin{array}{c}\text { Interaction } \\
\text { energy } \\
(\mathrm{kcal} / \mathrm{mol})\end{array}$ & $\begin{array}{c}\mathrm{Ki} \\
(\mu \mathrm{M})\end{array}$ & $\begin{array}{l}\text { Hydrogen } \\
\text { bond }\end{array}$ & Neighbouring amino acid residues \\
\hline 6-gingerol & -7.40 & 3.78 & $\begin{array}{l}\text { O-6gingerol } \rightarrow \\
\text { H-Arg } 120\end{array}$ & $\begin{array}{l}\text { Met113, Val116, Arg120, Ile345, Tyr348, Val349, } \\
\text { Leu352, Ser353, Tyr355, Leu359, Leu384, Tyr385, } \\
\text { Ile523, Gly526, Ala527, Ser530, Leu531 }\end{array}$ \\
\hline 6-shogaol & -7.27 & 4.66 & $\begin{array}{l}\text { O-6shogaol } \rightarrow \\
\text { H-Ser530 }\end{array}$ & $\begin{array}{l}\text { Met113, Val116, Arg120, Val349, Leu352, Ser353, } \\
\text { Tyr355, Leu359, Leu384, Tyr385, Ile523, Gly526, } \\
\text { Ala527, Ser530, Leu531 }\end{array}$ \\
\hline 6-paradol & -7.20 & 5.30 & - & $\begin{array}{c}\text { Met113, Arg120, Tyr348, Val349, Leu352, Ser353, } \\
\text { Tyr355, Leu359, Leu384, Tyr385, Ile523, Ala527, } \\
\text { Ser530, Leu531 }\end{array}$ \\
\hline SC-58 & -2.40 & $\begin{array}{l}0.02 \times \\
10^{6}\end{array}$ & - & $\begin{array}{c}\text { Phe205, Val344, Tyr348, Val349, Leu352, Leu384, } \\
\text { Tyr385, Trp387, Phe518, Met522, Ile523, Gly526, } \\
\text { Ala527, Ser530, Leu531, Leu534 }\end{array}$ \\
\hline \multicolumn{5}{|c|}{ COX-2 } \\
\hline 6-gingerol & -7.97 & 1.46 & $\begin{array}{c}\text { H-6gingerol } \rightarrow \\
\text { O-Tyr355 } \\
\text { O-6gingerol } \rightarrow \\
\text { H-Ser530 }\end{array}$ & $\begin{array}{l}\text { Val116, Arg120, Leu352, Ser353, Tyr355, Leu359, } \\
\text { Tyr385, Val523, Gly526, Ser530, Leu531 }\end{array}$ \\
\hline 6-shogaol & -8.10 & 1.16 & $\begin{array}{l}\text { O-6shogaol } \rightarrow \\
\text { H-Ser530 }\end{array}$ & $\begin{array}{l}\text { Arg120, Val349, Leu352, Tyr355, Tyr385, Trp387, } \\
\text { Phe518, Met522, Val523, Gly526, Ala527, Ser530, } \\
\text { Leu531 }\end{array}$ \\
\hline 6-paradol & -7.80 & 1.93 & $\begin{array}{l}\text { O-6paradol } \rightarrow \\
\text { H-Ser530 }\end{array}$ & $\begin{array}{l}\text { Arg120, Val349, Leu352, Tyr355, Tyr385, Trp387, } \\
\text { Phe518, Val523, Gly526, Ala527, Ser530, Leu531 }\end{array}$ \\
\hline SC-58 & -11.13 & $\begin{array}{c}6.98 \times \\
10^{-3}\end{array}$ & $\begin{array}{c}\mathrm{NH}_{2}-\mathrm{SC} 558 \rightarrow \\
\mathrm{O}-\mathrm{Ser} 353\end{array}$ & $\begin{array}{l}\text { His90, Arg120, Val349, Leu352, Ser353, Tyr355, } \\
\text { Tyr385, Trp387, Arg513, Val523, Gly526, Ala527 }\end{array}$ \\
\hline $\begin{array}{r}\text { cSI I } \\
(\mathrm{COX}-2 / \mathrm{C}\end{array}$ & & & 0.249 & $4.11 \times 10^{-7}$ \\
\hline
\end{tabular}

The interaction energy (scoring value) of the tested compound with COX-1 and COX-2 are similar, though they showed different $\mathrm{Ki}$ values, because the amino acid residues that interacted between the tested compound with both enzymes were different. $\mathrm{K}_{\mathrm{i}}$ represents binding affinity of the ligand to the enzyme. Smaller $\mathrm{K}_{\mathrm{i}}$ value shows stronger interaction. The $\mathrm{K}_{\mathrm{i}}$ values of the ligands interaction with COX-2 are smaller than COX-1 (Table 2), which mean that the ligands better interacted with $\mathrm{COX}-2$. The $\mathrm{K}_{\mathrm{i}}$ values of 6-gingerol, 6-shogaol, and 6-paradol greater than SC-58 $\left(6.98 \times 10^{-3} \mu \mathrm{M}\right)$, indicate that these compounds would probably require larger doses to obtain the same effect as SC-58.

COX-1 only form hydrogen bonding with 6-gingerol at Arg120 (1.915 $\AA$ ) and 6-shogaol at Ser530 (2.221 $\AA$ ). While in COX-2, 6-shogaol interact with Ser530 (2.032 $)$ ) and Tyr355 (2.156 $)$ ), 6-shogaol interact with Ser530

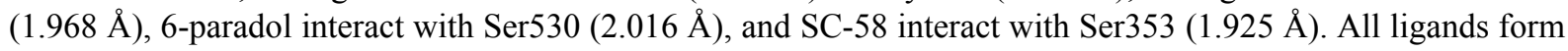
hydrophobic interaction with Arg120, Leu352, Leu384, Tyr385, Ile523, Ala527, Ser530, and Leu531 to COX-1. While in COX-2, only interact with Arg120, Leu352, Tyr385, Val523, and Gly526. Location of ligands at the binding pockets of COX-1 and COX-2 are the same. The difference of amino acid residues that interact with each ligand caused by different forms of each ligand conformation according to the conformational stability. The difference in the number of hydrogen bonds and hydrophobic interactions indicated the strength of enzyme-ligand interactions (Figure 3 and Figure 4).

Determination cSI (calculated selectivity indices or ratio of $\mathrm{K}_{\mathrm{i}} \mathrm{COX}-2 / \mathrm{K}_{\mathrm{i}} \mathrm{COX}-1$ ) was performed to study the selectivity of the ligand on COX-2. Classification cSI are i.e selective COX-2 inhibitor (cSI $<0.1)$, preferential COX-2 inhibitor $(\mathrm{cSI}=0.1$ to 1.0$)$, and nonselective COX-2 inhibitor $(\mathrm{cSI}>1.0)$ (Nunthanavanit \& Samee, 2011). 6-gingerol, 6-shogaol, and 6-paradol are classified as preferential COX-2 inhibitors, whereas SC-58 is a selective COX-2 inhibitor (Table 2). Based on this data, all studied ligands are potential to be developed as anti-inflammatory drugs. 


\section{Conclusion}

Phenolic compounds of ginger, which are 6-gingerol, 6-shogaol, and 6-paradol, could be developed as antiinflammatory drugs.

\section{References}

Chung, W. Y., Jung, Y. J., Surh, Y. J., Lee, S. S., \& Park, K. K. (2001). Antioxidative and antitumor promoting effects of 6-paradol and its homologs. Mutat. Res., 496, 268-270. Retrieved from http://www.ncbi.nlm.nih.gov/pubmed/11551496

Fabiola, G. F., Damodharan, L., Pattabhi, V., \& Nagarajan, K. (2001). Cyclooxygenase-2 an attractive target for fruitful drug design. Curr. Sci., 80, 26-34. Retrieved from http://www.iisc.ernet.in/currsci/jan102001/26.pdf

Ippoushi, K., Azuma, H., Ito, H., Horie, H., \& Higashio, H. (2003). 6-Gingerol inhibits nitric oxide synthesis in activated J774.1 mouse macrophages and prevents peroxynitrite-induced oxidation and nitration reactions. Life Sci., 73, 3427-3437. http://dx.doi.org/10.1016/j.lfs.2003.06.022

Kiuchi, F., Shibuya, M., \& Sankawa, U. (1982). Inhibitors of prostaglandin biosynthesis from ginger. Chem. Pharm. Bull., 30(2), 754-757. http://dx.doi.org/10.1248/cpb.30.754

Kurumbail, R. G., Steven, A. M., Gierse, J. K., McDonald, J. J., Stegeman, R. A., Pak, J. Y., ... Stallings, W. C. (1996). Structural basis for selective inhibition of cyclooxygenase-2 by anti-inflammatory agents. Nature, 384, 644-648. http://dx.doi.org/10.1038/384644a0

Levy, A. S., Simon, O., Shelly, J., \& Gardener, M. (2006). 6-Shogaol reduced chronic inflammatory response in the knees of rats treated with complete Freund's adjuvant. BMC Pharmacol, 6, 12. http://dx.doi.org/10.1186/1471-2210-6-12

Nunthanavanit, P., \& Samee, W. (2011). Molecular docking of natural product-derived compounds: estimation of selectivity on Cyclo-oxygenase-2. Thai Pharm. and Health Sci. J., 6(2), 79-85. Retrieved from http://ejournals.swu.ac.th/index.php/pharm/article/view/2437/2461

Picot, D., Loll, P. J., \& Garavito, R. M. (1994). The X-ray crystal structure of the membrane protein prostaglandin H2 synthase-1. Nature, 367, 243-249. http://dx.doi.org/10.1038/367243a0

\section{Copyrights}

Copyright for this article is retained by the author(s), with first publication rights granted to the journal.

This is an open-access article distributed under the terms and conditions of the Creative Commons Attribution license (http://creativecommons.org/licenses/by/3.0/). 